\title{
ANALISIS EFEKTIVITAS METODE PENYUSUTAN AKTIVA TETAP TERHADAP LABA PADA PT MAYORA INDAH TbK
}

\author{
Dwi Urip Wardoyo, Erna Rahmawati, Grace Yohana Rotua \\ Universitas Telkom Bandung Jawa Barat, Indonesia \\ Email: dwiurip@telkomuniversity.ac.id,ernarahmaw@student.telkomuniversity.ac.id, \\ gresyohana@student.telkomuniversity.ac.id
}

\begin{abstract}
Abstrak
Suatu perusahaan mengelola perusahaan untuk memaksimumkan perolehan laba atas penanaman investasi pada perusahaannya. Investasi tersebut berupa aktiva tetap dengan umur ekonomis lebih dari satu tahun. Aktiva tetap disusutkan secara tepat dengan metode penyusutan. Jumlah beban penyusutan aktiva tetap akan mempengaruhi perolehan laba suatu perusahaan. Penelitian ini bertujuan untuk mengetahui pengaruh efektivitas metode penyusutan aktiva tetap terhadap laba PT Mayora Indah Tbk. Penelitian ini menggunakan pendekatan kuantitatif dan metode komparatif. Teknik pengumpulan data yang digunakan adalah teknik dokumentasi berupa laporan keuangan PT Mayora Indah Tbk. periode 2017-2019. Hasil dari riset ini menunjukkan metode penyusutan garis lurus cenderung memiliki laba yang lebih besar dibandingkan dengan metode jumlah angka tahun ataupun metode saldo menurun. Hal ini dipengaruhi oleh jumlah beban penyusutan dengan metode garis lurus menghasilkan nilai tetap atau konstan setiap tahunnya.
\end{abstract}

Kata Kunci: aktiva tetap; metode penyusutan; laba

\section{Abstract}

A company manages the company to maximize the return on an investment in the company. The investment is in the form of fixed assets with an economic life of more than one year. Fixed assets are properly depreciated using the depreciation method. The amount of depreciation expense on fixed assets will affect the profit of a company. This study aims to determine the effect of the effectiveness of the fixed asset depreciation method on the profit of PT Mayora Indah Tbk. This research uses a quantitative approach and a comparative method. The data collection technique used is the documentation technique in the form of the financial statements of PT Mayora Indah Tbk. period 2017-2019. The results of this research show that the straight-line depreciation method tends to have a higher profit than the sum of years digits method or the declining balance method. This is influenced by the amount of depreciation expense using the straight-line method to produce a fixed or constant value every year.

Keywords: fixed assets; depreciation method; profit

Received: 2021-12-22; Accepted: 2022-01-05; Published: 2022-01-20

$\begin{array}{ll}\text { How to cite: } & \text { Wardoyo, D, U., Rahmawati, E., Rotua, G, Y., (2022) Analisis Efektivitas Metode Penyusutan Aktiva } \\ & \text { Tetap Terhadap Laba Pada PT Mayora Indah Tbk, Syntax Idea, 4(1), Https://Doi.Org/10.36418/syntax- } \\ & \text { idea.v4i1.1693 } \\ \text { E-ISSN: } & \text { 2684-883X } \\ \text { Published by: } & \text { Ridwan Institute }\end{array}$




\section{Pendahuluan}

Perkembangan usaha yang semakin maju, suatu perusahaan mempunyai tujuan dalam mengembangkan usahanya untuk mencapai profit yang diharapkan serta mempertahankan kontinuitas suatu perusahaan. Suatu perusahaan mengelola perusahaan untuk memaksimumkan perolehan laba atas penanaman investasi pada perusahaannya. Investasi tersebut berupa aktiva tetap dengan umur ekonomis lebih dari satu tahun. Aktiva tetap suatu perusahaan diperlukan dalam menjalankan kegiatan operasional perusahaan. Proses operasional perusahaan menggunakan berbagai jenis aktiva tetap, seperti bangunan, perlengkapan kantor, peralatan, dan kendaraan. Namun, nilai ekonomis suatu aktiva tetap mengalami depresiasi (penyusutan) yang disebabkan pemakaian, umur, kerusakaan, dan lain-lain, maka diperlukan pemeliharaan maupun pencatatan dengan memilih metode penyusutan yang tepat. Menurut (Mairuhu \& Tinangon, 2014) penyusutan adalah suatu metode dari akuntansi untuk mengalihkan biaya aktiva berwujud ke beban secara rasional dan sistematis, dimana bertujuan untuk memperoleh manfaat atas pemanfaatan aktiva tersebut.

Suatu perusahaan harus diharapkan dapat memilih atau mengaplikasikan metode penyusutan yang tepat pada aktiva tetap. Hal ini dikarenakan penggunaan metode penyusutan aktiva tetap yang berbeda akan memperoleh besaran beban depresiasi yang berbeda pula sehingga nantinya berdampak pada laba perusahaan. Biaya penyusutan aktiva tetap berkaitan erat dengan metode penyusutan yang diterapkan oleh perusahaan. Beban depresiasi masuk kedalam laporan laba rugi khususnya biaya operasional, sehingga besar kecilnya beban penyusutan aktiva tetap akan berdampak terhadap profit perusahaan.

Penelitian ini juga didukung oleh penelitian terdahulu yang dilakukan oleh (Nisa, 2016) mengenai Analisis PSAK No. 16 Tentang Akuntansi Aktiva Tetap Pada PT. Pelabuhan Indonesia I (Persero) Cabang Belawan.

PT Mayora Indah Tbk. adalah bagian dari perusahaan sektor manufaktur di Indonesia dengan spesialisasi industri pengolahan makanan dan minuman. PT Mayora Indah Tbk. didirikan pada tahun 1977 di Tangerang, Banten. Beberapa kegiatan usaha yang dijalankan PT Mayora Indah Tbk. diantaranya memproduksi wafer, coklat, biskuit, kopi, kembang gula serta makanan kesehatan (sereal). Kegiatan usaha tersebut tidak terlepas dari ketersediaan aktiva tetap dalam perusahaan. PT Mayora Indah Tbk. membangun pabrik baru di daerah Tangerang dalam rangka meningkatkan kinerja dan mendorong pertumbuhan penjualan, khususnya menambah kapasitas produksi biskuit dan wafer. Untuk mendukung serta memproses aktivitas operasional PT Mayora Indah Tbk. mempunyai aktiva tetap, diantaranya perlengkapan kantor, gedung, peralatan proyek, dan kendaraan yang digunakan untuk menunjang kelancaran operasional. Setiap tahunnya beban penyusutan PT Mayora Indah Tbk mengalami kenaikan, yang terlihat pada (Tabel 1). Hal ini dipengaruhi adanya peningkatan aset tetap dan aktivitas bisnis perusahaan (Rahmawaty et al., 2021). 


\section{Tabel 1}

Akumulasi Penyusutan PT Mayora Indah Tbk

Tahun Akumulasi Penyusutan (Rp)

\begin{tabular}{ll}
\hline 2017 & 3.859 .420 .029 .792 \\
\hline 2018 & 3.988 .757 .428 .380 \\
\hline 2019 & 4.258 .300 .525 .120 \\
\hline
\end{tabular}

Sumber :Laporan Keuangan PT Mayora Indah Tbk \& diolah penulis(2021)

Manajeman PT Mayora Indah Tbk. mengestimasikan masa manfaat ekonomis aktiva tetap antara 5-20 tahun. Umur masa manfaat ini diharapkan sesuai dengan perusahaan dimana perusahaan dan anak perusahaan mengelola bisnisnya. Oleh karena itu, perusahaan harus memperhatikan terkait jumlah beban pemeliharaan aktiva tetap apakah semakin meningkat atau konstan setiap tahun. Manajemen perusahaan diharapkan mempunyai prinsip bijaksana dalam menentukan keputusan atas revenue expenditure (pengeluaran pendapatan), serta pengeluaran aktiva tetap diluar batas minimal sehingga perlu dilakukan kapitalisasi yakni capital expenditure (pengeluaran modal).

Menurut (PSAK 16 2012), aktiva tetap adalah aktiva berwujud: pertama, digunakan untuk proses produksi barang atau jasa untuk disewakan kepada pihak lain, atau bertujuan sebagai administrasif, dan kedua, diperuntukkan penggunaannya lebih dari satu periode. (Warren et al., 2015) menyatakan aktiva tetap (fixed asset) adalah aktiva yang bersifat permanen atau jangka panjang, yang dimana sebagai suatu aset perusahaan yang dibeli namun tidak dijual, yang berguna untuk aktivitas operasional perusahaan. Menurut (Pontoh, 2013) aktiva tetap adalah suatu unsur fundamental yang dapat mendukung proses bisnis dalam mencapai laba. Karakteristik aktiva tetap menurut (PSAK 16 2012) sebagai berikut: Pertama, digunakan dalam operasi normal perusahaan. Kedua, memiliki masa umur ekonomis leih dari satu periode (panjang). Ketiga, memiliki sifat fisik (kasat mata).

Menurut (SAK, 2012) mengemukakan penyusutan adalah besaran penyusutan yang didistribusikan selama masa manfaat aktiva tetap pada setiap periode akuntansi. Aktiva tetap yang dapat disusutkan diantaranya bangunan, perlengkapan, peralatan, dan kendaraan. (Hery, 2014) mendefinisikan penyusutan adalah alokasi biaya perolehan aktiva tetap secara sistematis dan periodik dimana guna mendapatkan manfaat atas pemanfaatan aktiva tetap tersebut. Lalu definisi lain dalam penelitian (Martani et al., 2012) menyatakan bahwa penyusutan adalah skema alokasi aktiva tetap untuk disusutkan secara sistematis dalam sepanjang masa ekonomis aktiva tetap tersebut.

Menurut (Pontoh, 2013), terdapat faktor-faktor dalam mengestimasikan jumlah beban penyusutan sebagai berikut: pertama, Biaya perolehan (initial cost/capitalized), yaitu biaya-biaya yang dikeluarkan perusahaan dalam perolehan aset teap. kedua Umur manfaat (usefull life), yaitu lama masa pemanfaatan aset tetap. Ketiga, Nilai sisa/residu (residual value), yaitu perkiraan nilai aktiva tetap pada umur manfaat berakhir. keempat, Jumlah biaya yang dapat disusutkan (asset's depreciation cost), yaitu pengurangan dari 
biaya perolehan aktiva tetap dengan nilai residual. Kelima, Jumlah tercatat/nilai buku (book value), yaitu pengurangan dari biaya perolehan dengan akumulasi penyusutan.

Penelitian ini menggunakan tiga metode penyusutan aktiva tetap, diantaranya metode garis lurus, metode jumlah angka tahun, dan metode saldo menurun. Metode Garis Lurus (Straight Line Method) merupakan skema perhitungan penyusutan aktiva tetap dimana beban penyusutan akan sama (konstan) dengan syarat nilai residu tidak berubah. Pembebanan penyusutan jika menggunakan metode garis lurus akan memiliki besaran penyusutan yang sama setiap tahun, dimana hal ini sejalan dengan penelitian yang dilakukan oleh (Sari, 2018). Metode garis lurus dapat dinyatakan dalam rumus sebagai berikut:

$$
\text { Penyusutan }=\frac{\text { Harga Perolehan }- \text { Nilai Residu }}{\text { Taksiran Umur Ekonomis }}
$$

Metode Jumlah Angka Tahun (Sum of years digits method) merupakan suatu skema dalam perhitungan penyusutan aset tetap dengan mengalikan harga perolehan aktiva tetap dikurangi nilai residu dengan bagian pengurangan yang menurun setiap tahun. Penyusutan dalam metode jumlah angka tahun berbentuk pecahan, jika masa manfaat aktiva tetap 8 tahun maka penyebut angka pecahannya sebesar 36 , yang diperoleh dari penjumlahan $1+2+3+4+5+6+7+8$. Lalu angka pembilang dimulai dari angka $8,7,6,5,4,3,2,1$.

Metode Saldo Menurun (Diminishing Balance Method) ialah skema penyusutan aktiva tetap sesuai persentase tertentu yang dihitung dari nilai buku pada (book value). Metode jumlah menurun ini menghasilkan penyusutan yang menurun pada setiap tahun. Perhitungan metode penyusutan saldo menurun sebagai berikut:

$$
\begin{array}{ll}
\text { Tarif } & =(100 \%: \text { Umur Ekonomis }) \\
\text { Beban penyusutan } & =\text { tarif } \mathrm{x} \text { nilai buku awal tahun }
\end{array}
$$

Menurut (Kasmir, 2018) laporan keuangan adalah laporan yang memaparkan keadaan keuangan perusahaan pada suatu periode tertentu sehingga menunjukkan kondisi keuangan perusahaan berupa laporan posisi keuangan dan laporan laba rugi. Sedangkan, menurut (Suteja, 2018) laporan keuangan adalah report (laporan) yang menyajikan keadaan keuangan perusahaan atas suatu aktivitas akuntansi pada jangka waktu tertentu untuk kepentingan berbagai pihak.

Laporan laba rugi adalah laporan yang memberikan informasi mengenai pendapatan (penghasilan) serta beban-beban yang dikeluarkan perusahaan dalam suatu periode tertentu (Kasmir, 2018). Laporan laba rugi mempunyai 2 unsur utama dalam menilai kemampuan perusahaan dalam menghasilkan laba, yaitu revenus (pendapatan) dan expenses (beban). Pendapatan (revenues) adalah penghasilan yang timbulkan atas aktivitas, misalnya penjualan barang dagang, penghasilan jasa, sewa. Sedangkan beban (expense) adalah pengeluaran perusahaan berupa penurunan manfaat ekonomi (arus keluar), misalnya beban penyusutan, beban gaji dan upah, biaya telepon, beban listrik, 
beban pajak. Menurut (Subramanyam \& Wild, 2017) laba merupakan keuntungan yang dihasilkan perusahaan yang mencerminkan tingkat timbal balik untuk owner equity pada periode tertentu. Sedangkan menurut (Samryn, 2012) mengungkapkan bahwa laba adalah pendanaan internal yang didapatkan atas operasional perusahaan tanpa adanya tambahan biaya untuk pemakaian dan pemeliharaanya. Laba sebagai tolak ukur kinerja perusahaan, semakin tinggi laba perusahaan maka semakin baik operasional perusahaan. Penulis meneliti suatu pengaplikasian metode penyusutan aktiva tetap dan perhitungannya kedalam laporan keuangan. Penelitian ini bermanfaat untuk menentukan metode penyusutan aktiva tetap yang tepat sebaiknya digunakan pada PT Mayora Indah Tbk. Dengan demikian, pemilihan metode penyusutan yang tepat maka perusahaan akan dapat memperkirakan profit yang didapatkannya.

\section{Metode Penelitian}

Penelitian ini menggunakan konsep deskriptif-kuantitatif. Deskriptif-kuantitatif yaitu bentuk penggambaran data yang sesungguhnya, dengan mengumpulkan data untuk dianalisis sehingga didapatkan gambaran yang lebih jelas terkait objek yang diteliti. Adapun jenis data berupa data kuantitatif, yaitu data berbentuk angka sehingga dapat diolah guna menghasilkan kesimpulan. Sumber Data dalam penelitian ini adalah data sekunder pada laporan keuangan PT Mayora Indah Tbk pada tahun 2017-2019.

Teknik analisis data yaitu analisis deksriptif-kuantitatif dan komparatif. Deskriptif kuantitatif yaitu suatu riset yang menitikberatkan analisisnya pada angka (numerik) untuk menarik kesimpulan. Sedangkan, komparatif adalah penelitian dengan tujuan membandingkan suatu variabel penelitian guna mengetahui persamaan dan perbedaan, serta untuk menentukan metode penyusutan aktiva tetap mana yang lebih baik atau untuk dipilih.

\section{Hasil dan Pembahasan}

Tabel 1

Daftar Aktiva Tetap PT Mayora Indah Tbk.

\begin{tabular}{lccc}
\hline \multicolumn{1}{c}{ Aktiva Tetap } & $\begin{array}{c}\text { Harga Perolehan } \\
(\mathbf{R p})\end{array}$ & $\begin{array}{c}\text { Umur } \\
\text { Ekonomis }\end{array}$ & Tarif \\
\hline Bangunan dan prasarana & 1.364 .849 .962 .208 & 20 tahun & $5 \%$ \\
\hline Mesin dan peralatan & 5.394 .637 .738 .760 & 10 tahun & $12,5 \%$ \\
\hline Peralatan kantor & 177.116 .624 .242 & 5 tahun & $25 \%$ \\
\hline Kendaraan & 125.853 .233 .866 & 5 tahun & $25 \%$ \\
\hline Sumber: Laporan keuangan PT Mayora Indah Tbk \& diolah penulis (2021)
\end{tabular}


1. Analisis Metode Penyusutan Garis Lurus PT Mayora Indah Tbk.

Tabel 2

Beban Penyusutan Metode Garis Lurus

(dalam ribuan rupiah)

\begin{tabular}{|c|c|c|c|c|}
\hline \multicolumn{5}{|c|}{ Beban Penyusutan Metode Garis Lurus } \\
\hline No & Jenis Aktiva Tetap & $\begin{array}{c}\text { Beban } \\
\text { Penyusutan } \\
2017\end{array}$ & $\begin{array}{c}\text { Beban } \\
\text { Penyusutan } \\
2018\end{array}$ & $\begin{array}{c}\text { Beban } \\
\text { Penyusutan } \\
2019\end{array}$ \\
\hline 1 & Bangunan dan prasarana & 68.242 .498 & 68.242 .498 & 68.242 .498 \\
\hline 2 & Mesin dan peralatan & 539.463 .773 & 539.463 .773 & 539.463 .773 \\
\hline 3 & Peralatan kantor & 35.423 .324 & 35.423 .324 & 35.423 .324 \\
\hline 4 & Kendaraan & 25.170 .646 & 25.170 .646 & 25.170 .646 \\
\hline & JUMLAH & 668.300.241 & 668.300.241 & 668.300.241 \\
\hline
\end{tabular}

2. Analisis Metode Penyusutan Jumlah Angka Tahun PT Mayora Indah Tbk.

Tabel 3

Beban Penyusutan Metode Jumlah Angka Tahun

(dalam ribuan rupiah)

\begin{tabular}{|c|c|c|c|c|}
\hline \multicolumn{5}{|c|}{ Beban Penyusutan Metode Jumlah Angka Tahun } \\
\hline No. & Jenis Aktiva Tetap & Beban & Beban & Beban \\
\hline & & $\begin{array}{c}\text { Penyusutan } \\
2017\end{array}$ & $\begin{array}{c}\text { Penyusutan } \\
2018\end{array}$ & $\begin{array}{c}\text { Penyusutan } \\
2019\end{array}$ \\
\hline 1. & Bangunan Dan Prasarana & 129.985 .710 & 123.486 .425 & 116.987 .139 \\
\hline 2. & Mesin Dan Peralatan & 980.843 .225 & 882.758 .902 & 784.674 .580 \\
\hline 3. & Peralatan Kantor & 59.038 .874 & 47.231 .099 & 35.423 .324 \\
\hline 4. & Kendaraan & 41.951 .077 & 33.560 .862 & 25.170 .646 \\
\hline & Jumlah & 1.211.818.886 & 1.087.037.288 & 962.255 .689 \\
\hline
\end{tabular}

3. Analisis Metode Penyusutan Saldo Menurun PT Mayora Indah Tbk.

Tabel 4

Beban Penyusutan Metode Saldo Menurun (dalam ribuan rupiah)

\begin{tabular}{llrrr}
\hline \multicolumn{4}{c}{ Beban Penyusutan Metode Saldo Menurun } \\
\hline No & Jenis Aktiva Tetap & Beban & Beban & Beban \\
& & Penyusutan & Penyusutan & Penyusutan \\
& & 2017 & 2018 & 2019 \\
\hline 1 & Bangunan dan prasarana & 68.242 .498 & 64.830 .373 & 61.588 .854 \\
\hline 2 & Mesin dan peralatan & 674.329 .717 & 590.038 .502 & 516.283 .689 \\
\hline 3 & Peralatan kantor & 44.279 .156 & 33.209 .367 & 24.907 .025 \\
\hline 4 & Kendaraan & 31.463 .308 & 23.597 .481 & 17.698 .111 \\
\hline & JUMLAH & $\mathbf{8 1 8 . 3 1 4 . 6 7 9}$ & $\mathbf{7 1 1 . 6 7 5 . 7 2 3}$ & $\mathbf{6 2 0 . 4 7 7 . 6 7 9}$ \\
\hline
\end{tabular}




\section{Pengaruh Penggunaan Metode Penyusutan Aktiva Tetap Terhadap Laporan Laba}

Setelah dilakukan perhitungan beberapa metode penyusutan aktiva tetap, maka dapat diketahui perbandingan perolehan laba adalah sebagai berikut:

\section{Tabel 5}

Rincian Metode Penyusutan Terhadap Laba Tahun 2017 (dalam ribuan rupiah)

\begin{tabular}{lrrr}
\hline \multirow{2}{*}{ Keterangan } & \multicolumn{3}{c}{ Metode Penyusutan 2017 } \\
\cline { 2 - 4 } & \multicolumn{1}{c}{$\begin{array}{c}\text { Metode Garis } \\
\text { Lurus }\end{array}$} & $\begin{array}{c}\text { Metode Jumlah } \\
\text { Angka Tahun }\end{array}$ & $\begin{array}{c}\text { Metode Saldo } \\
\text { Menurun }\end{array}$ \\
\hline Penjualan Bersih & 20.816 .673 .946 & 20.816 .673 .946 & 20.816 .673 .946 \\
Beban Pokok Penjualan & 15.841 .619 .191 & 15.841 .619 .191 & 15.841 .619 .191 \\
\hline Laba Bruto & $\mathbf{4 . 9 7 5 . 0 5 4 . 7 5 5}$ & $\mathbf{4 . 9 7 5 . 0 5 4 . 7 5 5}$ & $\mathbf{4 . 9 7 5 . 0 5 4 . 7 5 5}$ \\
\hline Beban Usaha & & & \\
Beban Penjualan & 1.909 .467 .278 & 1.909 .467 .278 & 1.909 .467 .278 \\
Beban Umum dan administrasi & 605.008 .088 & 605.008 .088 & 605.008 .088 \\
Beban Penyusutan & 668.300 .243 & 1.211 .818 .886 & 818.314 .679 \\
\hline Jumlah Beban Usaha & $\mathbf{3 . 1 8 2 . 7 7 5 . 6 0 9}$ & $\mathbf{3 . 7 2 6 . 2 9 4 . 2 5 2}$ & $\mathbf{3 . 3 3 2 . 7 9 0 . 0 4 5}$ \\
\hline Laba Usaha & $\mathbf{1 . 7 9 2 . 2 7 9 . 1 4 6}$ & $\mathbf{1 . 2 4 8 . 7 6 0 . 5 0 3}$ & $\mathbf{1 . 6 4 2 . 2 6 4 . 7 1 0}$ \\
\hline \% Laba & $\mathbf{0 , 5 6}$ & $\mathbf{0 , 3 4}$ & $\mathbf{0 , 4 9}$ \\
\hline
\end{tabular}

Tabel 6

Rincian Metode Penyusutan Terhadap Laba Tahun 2018 (dalam ribuan rupiah)

\begin{tabular}{llll}
\hline \multirow{2}{*}{\multicolumn{1}{c}{ Keterangan }} & \multicolumn{3}{c}{ Metode Penyusutan 2018 } \\
\cline { 2 - 4 } & \multicolumn{1}{c}{$\begin{array}{c}\text { Metode Garis } \\
\text { Lurus }\end{array}$} & $\begin{array}{c}\text { Metode Jumlah } \\
\text { Angka Tahun }\end{array}$ & $\begin{array}{c}\text { Metode Saldo } \\
\text { Menurun }\end{array}$ \\
\hline Penjualan Bersih & 24.060 .802 .395 & 24.060 .802 .395 & 24.060 .802 .395 \\
Beban Pokok Penjualan & 17.664 .148 .865 & 17.664 .148 .865 & 17.664 .148 .865 \\
\hline Laba Bruto & $\mathbf{6 . 3 9 6 . 6 5 3 . 5 3 0}$ & $\mathbf{6 . 3 9 6 . 6 5 3 . 5 3 0}$ & $\mathbf{6 . 3 9 6 . 6 5 3 . 5 3 0}$ \\
\hline Beban Usaha & & & \\
Beban Penjualan & 3.045 .558 .342 & 3.045 .558 .342 & 3.045 .558 .342 \\
Beban Umum dan administrasi & 723.203 .180 & 723.203 .180 & 723.203 .180 \\
Beban Penyusutan & 668.300 .241 & 1.087 .037 .288 & 711.675 .723 \\
\hline Jumlah Beban Usaha & $\mathbf{4 . 4 3 7 . 0 6 1 . 7 6 3}$ & $\mathbf{4 . 8 5 5 . 7 9 8 . 8 1 0}$ & $\mathbf{4 . 4 8 0 . 4 3 7 . 2 4 5}$ \\
\hline Laba Usaha & $\mathbf{1 . 9 5 9 . 5 9 1 . 7 6 7}$ & $\mathbf{1 . 5 4 0 . 8 5 4 . 7 2 0}$ & $\mathbf{1 . 9 1 6 . 2 1 6 . 2 8 5}$ \\
\hline \% Laba & $\mathbf{0 , 4 4}$ & $\mathbf{0 , 3 2}$ & $\mathbf{0 , 4 3}$ \\
\hline
\end{tabular}


Tabel 7

Rincian Metode Penyusutan Terhadap Laba Tahun 2019

(dalam ribuan rupiah)

\begin{tabular}{lrrr}
\hline \multicolumn{1}{c}{ Keterangan } & \multicolumn{3}{c}{ Metode Penyusutan 2019 } \\
\cline { 2 - 4 } & $\begin{array}{c}\text { Metode Garis } \\
\text { Lurus }\end{array}$ & $\begin{array}{c}\text { Metode Jumlah } \\
\text { Angka Tahun }\end{array}$ & $\begin{array}{c}\text { Metode Saldo } \\
\text { Menurun }\end{array}$ \\
\hline Penjualan Bersih & 25.026 .739 .472 & 25.026 .739 .472 & 25.026 .739 .472 \\
Beban Pokok Penjualan & 17.109 .498 .526 & 17.109 .498 .526 & 17.109 .498 .526 \\
\hline Laba Bruto & $\mathbf{7 . 9 1 7 . 2 4 0 . 9 4 6}$ & $\mathbf{7 . 9 1 7 . 2 4 0 . 9 4 6}$ & $\mathbf{7 . 9 1 7 . 2 4 0 . 9 4 6}$ \\
\hline Beban Usaha & & & \\
Beban Penjualan & 4.027 .986 .833 & 4.027 .986 .833 & 4.027 .986 .833 \\
Beban Umum dan administrasi & 716.989 .561 & 716.989 .561 & 716.989 .561 \\
Beban Penyusutan & 668.300 .241 & 962.255 .689 & 620.477 .679 \\
\hline Jumlah Beban Usaha & $\mathbf{5 . 4 1 3 . 2 7 6 . 6 3 5}$ & $\mathbf{5 . 7 0 7 . 2 3 2 . 0 8 3}$ & $\mathbf{5 . 3 6 5 . 4 5 4 . 0 7 3}$ \\
\hline Laba Usaha & $\mathbf{2 . 5 0 3 . 9 6 4 . 3 1 1}$ & $\mathbf{2 . 2 1 0 . 0 0 8 . 8 6 3}$ & $\mathbf{2 . 5 5 1 . 7 8 6 . 8 7 3}$ \\
\hline \% Laba & $\mathbf{0 , 4 6}$ & $\mathbf{0 , 3 9}$ & $\mathbf{0 , 4 8}$ \\
\hline
\end{tabular}

Berdasarkan pada tabel perbandingan diatas, penulis membandingkan persentase laba berdasarkan masing-masing metode penyusutan aktiva tetap serta periodenya. Pada tahun 2017, apabila menerapkan metode garis lurus diperoleh persentase laba senilai $0,56 \%$, dengan menerapkan metode saldo menurun senilai $0,49 \%$ dan metode jumlah angka tahun senilai $0,34 \%$. Sedangkan, persentase laba perusahaan pada tahun 2018 apabila menerapkan metode garis lurus senilai $0,44 \%$, dengan menggunakan metode saldo menurun senilai $0,43 \%$ dan metode jumlah angka tahun senilai $0,32 \%$. Lalu tahun 2019 , persentase laba apabila menerapkan metode garis lurus senilai $0,46 \%$, dengan metode saldo menurun senilai $0,48 \%$ dan metode jumlah angka tahun senilai $0,39 \%$.

\section{Kesimpulan}

Berdasarkan hasil penelitian pada Tabel 2 hingga Tabel 7, maka dapat ditarik kesimpulan sebagai berikut: (1.) Besarnya depresiasi aktiva tetap dengan metode penyusutan garis lurus adalah tetap (konstan) setiap tahunnya yaitu senilai Rp 668.300.241. Oleh karena itu, metode penyusutan garis lurus yang telah diaplikasikan pada PT Mayora Indah Tbk. sudah sesuai karena akan membebankan penyusutan tetap (konstan) pada setiap tahunnya. Hal ini sejalan dengan penelitian yang dilakukan oleh siagian dan putri tahun 2019, tarigan tahun 2021 dan sihombing tahun 2016 yang menyatakan bahwa penerapan metode penyusutan garis lurus sudah tepat. (2.) Jika menerapkan metode penyusutan jumlah angka tahun, penyusutan tahun 2017 senilai $\mathrm{Rp}$ 1.211.818.886, pada tahun 2018 penyusutan senilai Rp 1.087.037.288 serta tahun 2019 penyusutan senilai $\mathrm{Rp}$ 962.255.689. Hal ini berarti mengalami penurunan dari tahun ke tahun. (3.) Jika menerapkan metode penyusutan saldo menurun, penyusutan tahun 2017 senilai Rp 818.314.679, sedangkan pada tahun 2018 penyusutan senilai Rp711.675.723 
serta pada tahun 2019 penyusutan senilai 620.477.679, yang dimana penyusutan mengalami penurunan dari tahun ke tahun.

\section{BIBLIOGRAFI}

Bursa Efek Indonesia. (2014). Laporan Keuangan PT Mayora Indah Tbk. Tahun 20172019. Bursa Efek IndonesIa.

Hery. (2014). Akuntansi Dasar 1 dan 2. Kompas Gramedia.

Ikatan Akuntansi Indonesia. (2012). Standar Akuntansi Keuangan. Ikatan Akuntansi Indonesia. Google Scholar

Kasmir. (2018). Analisis Laporan Keuangan. Rajawali Pers.

Mairuhu, S., \& Tinangon, J. J. (2014). Analisis Penerapan Metode Penyusutan Aktiva Tetap dan Implikasinya Terhadap Laba Perusahaan Pada Perum Bulog Divre Sulut dan Gorontalo. Jurnal Emba: Jurnal Riset Ekonomi, Manajemen, Bisnis Dan Akuntansi, 2(4).

Martani, D., Siregar, S. V., Wardhani, R., Farahmita, A., \& Tanujaya, E. (2012). Akuntansi Keuangan Menengah Berbasis PSAK. Salemba Empat. Google Scholar

Nisa, R. (2016). Cooperative Teaching-Learning using the Fishbowl Technique for teaching reading. English Education Journal, 7(3), 298-310. Google Scholar

Pontoh, W. (2013). Akuntansi Konsep dan Aplikasi. Moeka. Google Scholar

Rahmawaty, A., Giningroem, D. S. W. P., Vikaliana, R., \& Setyawati, N. W. (2021). Analisis Penyusutan Aktiva Tetap dan Pengaruhnya Terhadap Laba Perusahaan Pada PT Aneka Gas Industri. Neraca: Jurnal Akuntansi Terapan, 2(2). Google Scholar

Samryn, L. M. (2012). Akuntansi Manajemen Informasi Biaya untuk Mengendalikan Aktivitas Operasi dan Investasi (1st ed.). Kencana Prenada Media Group. Google Scholar

Sari, D. I. (2018). Analisis Depresiasi Aktiva Tetap Metode Garis Lurus dan Jumlah Angka Tahun PT Adira Dinamika. Jurnal Moneter, 5(1). Google Scholar

Subramanyam, K. R., \& Wild, J. J. (2017). Analisis Laporan Keuangan (11th ed.). Salemba Empat.

Suteja, I. G. N. (2018). Analisis Kinerja Keuangan dengan Metode Altman Z Score pada PT. Ace Hardware Indonesia Tbk. Moneter: Jurnal Akuntansi Dan Keuangan, 5(1). Google Scholar

Warren, C. S., Reeve, J. M., Duchac, J. E., Suhardianto, N., Kalanjati, D. S., Jusuf, A. 
Dwi Urip Wardoyo, Erna Rahmawati, Grace Yohana Rotua

A., \& Djakman, C. D. (2016). Pengantar Akuntansi (25th ed.). Salemba Empat. Google Scholar

Copyright holder:

Dwi Urip Wardoyo, Erna Rahmawati, Grace Yohana Rotua (2022)

First publication right:

Syntax Idea

This article is licensed under:

(c) (i) (?) 